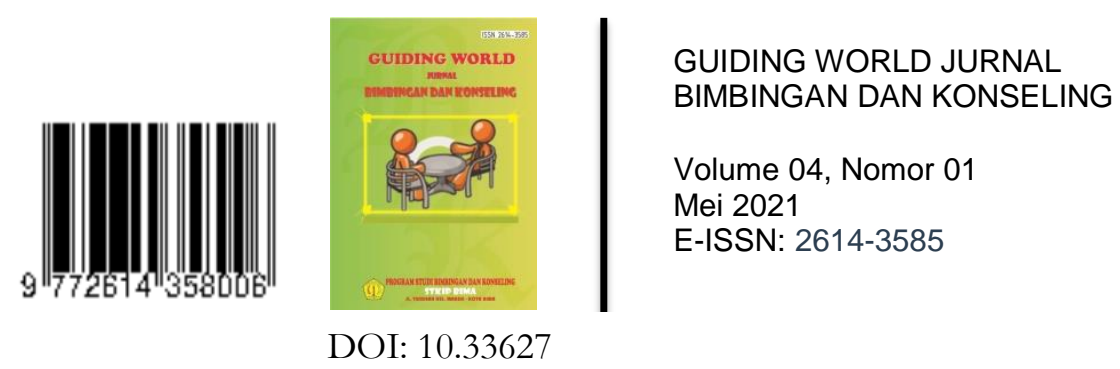

\title{
Pengaruh Peer Group Terhadap Motivasi Belajar Siswa Smp Negeri 8 Kota Bima Tahun Pelajaran 2020 / 2021
}

\author{
Nur Syariful Amin, Khairunnisa, Sulistia Indah \\ Prodi Bimbingan dan Konseling, Sekolah Tinggi Keguruan Dan Ilmu Pendidikan (STKIP) Bima \\ Email: amin.stkipbima@gmail.com
}

Abstrak :

Peer group adalah sekelompok teman sebaya yang mempunyai ikatan emosional yang kuat dan mereka dapat berinteraksi, bergaul, bertukar pikiran, dan pengalaman dalam memberikan perubahan dan pengembangan dalam kehidupan sosial dan pribadi anggota.Sedangkan motivasi pada dasarnya dapat membantu dalam memahami dan menjelaskan perilaku individu termasuk perilaku individu yang sedang belajar. Penelitian ini ditujukan untuk mengetahui pengaruh peer group terhadap motivasi belajar siswa.

Penelitian ini dilakukan di SMP Negeri 8 Kota Bima. Subyek dalam penelitian ini yaitu seluruh siswa kelas VIII yang tergabung dalam 8 peer group dengan jumlah 31 orang siswa. Penelitian ini termasuk penelitian kuantitatif karena menggunakan rancangan empiris dan gejala yang diamati telah ada secara wajar tampa harus memanipulasi terlebih dahulu. Instrumen pengumpulan data dalam penelitian ini adalah observasi, angket dan dokumentasi. Angket dianalisa dengan menggunakan analisis statistik deskriptif melalui rumus korelasi product moment. Dari hasil analisis data kualitatif diketahui bahwa nilai korelasi product moment (r) adalah 0,43 (43\%). Sehingga dengan menggunakan kaidah pengambilan keputusan dalam uji statistik maka dapat disimpulkan bahwa hipotesis alternatif ( $\mathrm{Ha}$ ) yang berbunyi : ada pengaruh peer group terhadap motivasi belajar siswa di SMPN 8 Kota Bima, dapat diterima

Kata Kunci : Peer Group, Motivasi Belajar

\section{PENDAHULUAN}

Belajar merupakan proses internal yang kompleks. Yang terlibat dalam proses internal tersebut adalah seluruh mental yang meliputi ranah-ranah kognitif, afektif, dan psikomotorik. Proses belajar yang mengaktualisasikan ranah-ranah tersebut tertuju pada bahan belajar tertentu. Sedangkan dinamisasi dari luar dapat berasal dari guru atau pembelajar dilingkungannya.

Dalam perilaku belajar terdapat motivasi belajar. Motivasi pada dasarnya merupakan upaya untuk membantu dalam memahami dan menjelaskan perilaku individu yang sedang belajar. Motivasi dan belajar merupakan dua hal yang saling mempengaruhi. Belajar menurut. Hamzah B.Uno dalam buku Teori Motivasi (2008) adalah perubahan tingkah laku secara relatif permanen dan secara potensial terjadi sebagai hasil dari praktik atau penguatan yang dilandasi tujuan untuk mencapai tujuan tertentu..

Sedangkan hakikat motivasi belajar itu sendiri menurut pendapat yang sama dari Hamzah B.Uno (2008) menyatakan bahwa Motivasi belajar adalah dorongan internal dan eksternal 

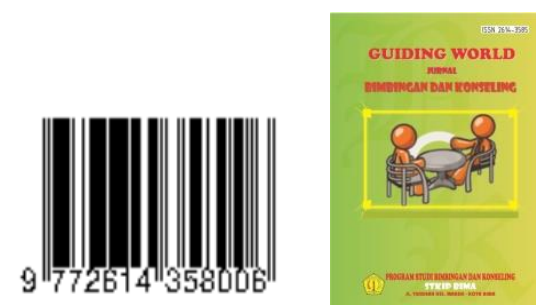

GUIDING WORLD JURNAL

BIMBINGAN DAN KONSELING

Volume 04, Nomor 01

Mei 2021

E-ISSN: 2614-3585

DOI: 1033627

pada siswa-siswa yang sedang belajar untuk mengadakan perubahan tingkah laku pada umumnya dengan beberapa indikator atau unsur yang mendukung.

Peer group adalah kelompok teman anak sebaya yang sukses dimana dia dapat berinteraksi Santoso (1995) Dalam kelompok teman sebaya individu merasakan adanya kesamaan satu dengan yang lainnya seperti dibidang usia, kebutuhan, dan tujuan yang dapat memperkuat kelompok itu. Didalam peer group tidak dipentingkan adanya struktur organisasi, namun diantara anggota kelompok merasakan adanya tanggung jawab atas keberhasilan dan kegagalan kelompoknya.

Dalam peer group ini, individu menemukan dirinya (pribadi) serta dapat mengembangkan rasa sosialnya sejalan dengan perkembangan kepribadiannya. Sedangkan menurut pakar psikologi remaja Santrock, Certwringht dan Zander (www Kompas.com) peer group adalah sekumpulan remaja sebaya yang punya hubungan erat dan saling tergantung. Di sekolah atau dilingkungan tempat tinggal kita biasanya ada kelompok "pertemanan", mereka terdiri atas beberapa orang yang merasa punya ikatan kuat. Mereka kelihatan selalu bersamasama dalam melakukan berbagai aktivitas.

Berdasarkan kondisi obyektif yang telah diuraikan oleh peneliti diatas, maka rumusan masalah dari penelitian ini adalah apakah ada pengaruh peer group terhadap motivasi belajar siswa SMPN 8 Kota Bima..

\section{KERANGKA TEORITIS DAN PENGEMBANGAN HIPOTESIS}

\section{Lingkungan Keluarga}

Lingkungan keluarga adalah lingkungan terkecil dalam kestuan masyarakat. Keluarga dibangun dari sebuah perkawinan antara seorang laki-laki dengan seorang wanita, kemudian hidup bersama dan menghasilkan keturunan berupa anak. Maka yang bertanggung jawab dalam sebuah keluarga adalah orang tua. Hal tersebut seperti yang dikemukakan oleh Gunarsa (2009 : 5) bahwa lingkungan keluarga merupakan "lingkungan pertama yang mula-mula memberikan pengaruh yang mendalam bagi anak". Dari anggota-anggota keluarganya (ayah, ibu dan saudara-saudaranya) anak memperoleh segala kemampuan dasar, baik intelektual maupun sosial. Setiap sikap, pandangan dan pendapat orang tua atau anggota keluarga lainnya akan dijadikan contoh oleh anak dalam berperilaku. Demikian juga dengan pendapat Sadjaah (2002) yang mengemukakan bahwa "Lingkungan keluarga merupakan unit terkecil dalam masyarakat memiliki nuclear family maupun extended family, yang secara nyata mendidik kepribadian seseorang dan mewariskan nilai-nilai budaya melalui interaksi sesame anggota dalam mencapai tujuan". Dalam hal ini berarti lingkungan keluarga sebagai lingkungan pendidikan yang pertama ini sangat penting dalam membentuk pola kepribadian anak. Karena di dalam keluarga, anak pertama kali mendapat pengetahuan tentang nilai dan norma.

Pendapat lainnya tentang lingkungan keluarga yaitu menurut Hasbullah (2008:38) yaitu "Lingkungan keluarga merupakan lingkungan pendidikan pertama dan utama bagi anak, karena dalam keluarga inilah anak pertama-tama mendapat didikan dan bimbingan. Dan dikatakan sebagai lingkungan yang utama karena sebagian besar dari kehidupan anak adalah di dalam keluarga." Kemudian Barnadib (2002 : 120) mengemukakan "lingkungan keluarga yaitu lingkungan yang bertanggung jawab atas kelakuan, pembentukkan kepribadian, kasih sayang, perhatian, bimbingan, kesehatan dan suasana rumah. Dari lingkungan keluarga yang harmonis yang mampu memancarkan keteladanan kepada anak-anaknya, akan lahir anak-anak 


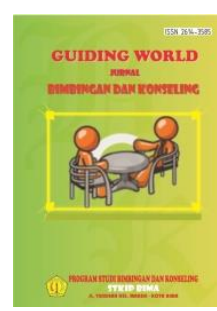

DOI: 1033627

yang memliki kepribadian dengan pola yang mantap, Sementara dalam Undang-Undang Sistem Pendidikan Nasional No. 2/1989 menyatakan secara jelas bahwa keluarga merupakan bagian dari jalur pendidikan luar sekolah yang memberikan keyakinan agama, nilai budaya, nilai-nilai moral, dan keterampilan. Di lingkungan keluarga anak mendapatkan perhatian, kasih sayang, dorongan, bimbingan, keteladanan dan pemenuhan kebutuhan ekonomi dari orang tua sehingga anak dapat mengembangkan segala potensi yang dimilikinya demi perkembangannya di masa mendatang

Dari uraian-uraian tersebut, maka dapat disimpulkan bahwa lingkungan keluarga adalah segala sesuatu yang berada di sekitar individu yang merupakan hubungan dan peranan yang sangat penting dalam perkembangan individu yang mempunyai ikatan-ikatan, baik ikatan perkawinan, darah ataupun adopsi. dan lingkungan keluarga juga adalah segala sesuatu yang disekelilingi manusia yang dapat mempengaruhi tingkah laku secara langsung maupun tidak langsung. Kehidupan manusia selalu berhubungan dengan lingkungan yang didalamnya diperlukan suatu interaksi dengan sesama manusia, baik secara individual maupun kelompok, sebab bagaimanapun manusia tumbuh dan berkembang terutama di lingkungannya.

\section{Peran Lingkungan Keluarga}

Keluarga sudah dikenal sebagai lingkungan perndidikan yang pertama dan utama, (Gunarso, 2000:33). Predikat ini mengindikasikan betapa esensialnya peran dan pengaruh lingkungan keluarga dalam pembentukan perilaku dan kepribadian anak. Pandangan ini sangat logis dan mudah dipahami karena beberapa alaan sebagai berikut:

Pertama, keluarga lazimnya merupakan pihak yang paling awal memberikan banyak perlakuan kepada anak. Begitu anak lahir, lazimnya pihak keluargalah yang langsung menyambut dan memberikan layanan interaktif kepada anak. Apa yang dilakukan dan diberikan oleh pihak keluarga menjadi sumber perlakuan pertama yang akan mempengaruhi pembentukan karakteristik pribadi dan perilaku anak. Menurut banyak ahli pengalaman hidup pada masa awal akan menjadi fondasi bagi proses perkembangan dan pembelajran anak selanjutnya.

Kedua, sebagian besar waktu anak lazimnya dihabiskan di lingkungan keluarga. Kalau di sekolah anak menghabiskan waktu sekitar 5-6 jam, maka di rumah anak bisa menghabikan waktu sekitar dua kali lipat atau lebih dari itu. Besarnya peluang dan interaksi akan sangat besar pengaruhnya pada perkembangan anak.

Ketiga, karakteristik hubungan orangtua- anak berbeda dari hubungan anak dengan pihak-pihak lainnya (guru, teman, dsb). Kepada orangtua disamping anak memiliki ketergantungan secara materi, ia juga memiliki ikatan psikologi tertentu yang sejak dalam kandungan sudah dibangun melalui jalinan kasih saying dan pengaruh- pengaruh normatif tertentu.Keempat, interaksi kehidupan orangtua- anak di rumah bersifat "asli", seadanya dan tidak dibuat-buat.

\section{Fungsi Lingkungan Keluarga}

Pada dasarnya, keluarga memiliki tanggung jawab atas tiap-tiap anggotanya dimanadalam keluarga diselenggarakan fungsi keluarga. Fungsi keluarga adalah suatu pekerjaan - pekerjaan atau tugas - tugas yang harus dilaksanakan di dalam atau oleh keluarga itu sendiriuntuk menumbuhkembangkan angoota-anggotanya. Pekerjaan-pekerjaan yang harus dikerjakan oleh keluarga itu dapat digolongkan ke dalam beberapa fungsi, (Hasbullah, 


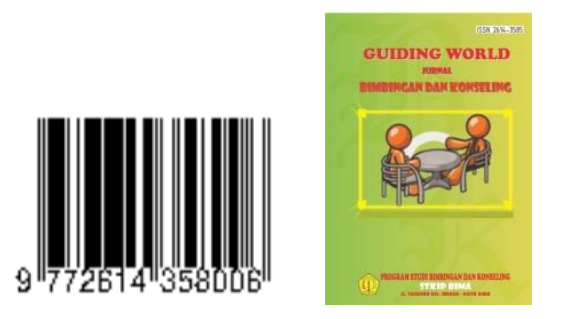

2008:12) yaitu : a. Fungsi Biologis, b. Fungsi Ekonomi,c. Fungsi Pemeliharaan, d. Fungsi Keagamaan, e. Fungsi Sosial, dan f. Fungsi Sosialisasi dan Pendidikan

\section{Karakteristik Keluarga}

Adapun karakteristik keluarga yang juga terdapat pada semua keluarga dan juga untuk membedakan keluarga dari kelompok-kelompok sosial. Menurut Gunarso (200:39) ada empat karakteristik keluarga yaitu:

a. Keluarga adalah susunan orang-orang yang disatukan oleh ikatan- ikatan perkawinan darah atau adopsi.

b. Anggota-anggota keluarga ditandai dengan hidup bersama dibawah satu atap merupakan susunan satu rumah tangga, atau jika mereka bertempat tinggal, rumah tangga tersebut menjadi rumah mereka.

c. Keluarga merupakan kesatuan dari orang-orang yang berinteraksi dan berkomunikasi yang menciptakan perana-peranan sosial bagi suami dan istri, ayah, ibu, putra dan putri, saudara laki-laki dan saudara perempuan.

d. Keluarga adalah pemelihara suatu kebudayaan bersama, yang diperoleh pada hakikatnya dari kebudayaan umum, tetapi dalam suatu masyarakat yang komplek masing-masing keluarga mempunyai ciri-ciri yang berlainan dengan keluarga lainnya. Berbedanya kebudayaan dari setiap keluarga timbul melalui kominikasi anggota-anggota keluarga yang merupakan gabungan dari pola-pola tingkah laku individu.

\section{Faktor-Faktor yang Mempengaruhi Perkembangan Anak dalam Lingkungan Keluarga}

Seiring perjalanan hidupnya yang diwarnai faktor internal (kondisi fisik, psikis dan moralitas anggota keluarga) dan faktor eksternal (perubahan sosial budaya, maka setiap keluarga mengalami perubahan yang beragam. Ada keluarga yang kokoh dalam menerapkan fungsinya (fungsinonal- normal) tapi ada juga keluarga yang mengalami keretakan atau ketidakharmonisan (disfungsional atau tidak normal). Keluarga yang fungsional (normal) yaitu kelurga yang telah mampu melaksanakan fungsinya sebagai mana yang sudah dijelaskan. Disamping itu, keluarga yang fungsional ditandai oleh karakteristik : saling memperjatikan dan mencintai, bersikap terbuka dan jujur, orang tua mau mendengarkan anak,menerima perasaannya dan menghargai pendapatnya, dan ada "sharing" masalah atau pendapat diantara anggota keluarga.

\section{Kemandirian Belajar}

Mandiri berarti mampu bertindak sesuai keadaan tanpa meminta atau tergantung pada orang lain. Mandiri adalah dimana seseorang mau dan mampu mewujudkan kehendak/keinginan dirinya yang terlihat dalam tindakan/perbuatan nyata guna menghasilkan sesuatu (barang/jasa) demi pemenuhan kebutuhan hidupnya dan sesamanya (Antonius, 2002:145). Sementara Kemandirian menurut Eddy Wibwo (1992:69)) adalah sebagai tingkat perkembangan seseorang dimana ia mampu berdiri sendiri dan mengandalkan kemampuan dirinya sendiri dalam melakukan berbagai kegiatan dan menyelesaikan berbagai masalah yang dihadapi. Sedangkan Kemandirian Menurut Masrun (2001:8) adalah suatu sikap yang memungkinkan seseorang untuk bertindak bebas, melakukan sesuatu atas dorongan sendiri dan untuk kebutuhannya sendiri tanpa bantuan dari orang lain, maupun berpikir dan bertindak 



GUIDING WORLD JURNAL

BIMBINGAN DAN KONSELING

DOI: 1033627

Volume 04, Nomor 01

Mei 2021

E-ISSN: 2614-3585

original/kreatif, dan penuh inisiatif, mampu mempengaruhi lingkungan, mempunyai rasa percaya diri dan memperoleh kepuasan dari usahanya. Sedangkan Belajar diartikan sebagai suatu proses usaha yang dilakukan individu untuk memperoleh suatu perubahan perilaku yang baru secara keseluruhan, sebagai hasil dari pengalaman individu itu sendiri dalam interaksi individu dengan lingkungannya.

Dari beberapa pendapat para ahli dapat disimpulkan bahwa kemandirian belajar adalah kondisi aktifitas Belajar yang mandiri tidak tergantung pada orang lain, memiliki kemauan, inisiatif serta bertanggung jawab sendiri dalam menyelesaikan masalah belajarnya. Kemandirian Belajar akan terwujud apabila siswa aktif mengontrol sendiri segala sesuatu yang dikerjakan, mengevaluasi dan selanjutnya merencanakan sesuatu yang lebih dalam pembelajaran yang dilalui dan siswa juga mau aktif dalam proses pembelajaran.

\section{Ciri-ciri Kemandirian Belajar}

Abu Ahmadi (2000:13), merumuskan ciri-ciri kemandirian mandiri sebagai berikut: 1) Mampu mengambil inisiatif. 2) Mampu mengatasi masalah. 3) Penuh ketekunan. 4) Memperoleh kepuasan dari hasil usahanya. 5) Berkeinginan mengerjakan sesuatu tanpa bantuan orng lain. Sementara Menurut Sukarno (2001:64) menyebutkan siswa atau peserta didk yang memiliki ciri-ciri Kemandirian Belajar ditandai dengan hal-hal sebagai berikut: 1) Siswa merencanakan dan memilih kegiatan Belajar sendiri 2) Siswa berinisiatif dan memacu diri untuk Belajar secara terus menerus 3) Siswa dituntut bertanggung jawab dalam Belajar 4) Siswa Belajar secara kritis, logis, dan penuh keterbukaan 5) Siswa Belajar dengan penuh percaya diri. Sedangkan menurut Hiemstra (2001:23), siswa atau peserta didk yang memiilki Kemandirian belajar.memiliki ciri-ciri: a) Siswa tersebut mempunyai tanggung jawab dalam pengambilan keputusan yang berhubungan dengan usaha pembelajaran b) Belajar mandiri merupakan karakteristik yang dapat digunakan setiap individu dalam setiap situasi c) Belajar mandiri bukan mengisolasi diri individu dengan orang lain d) Individu yang mempunyai Kemandirian Belajar mampu untuk "transfer learning", baik pengetahuan maupun keahlian (skill) dari satu situasi ke situasi yang lain seperti berpartisipasi dalam grup, latihan - latihan, dialog secara elektronik, dan aktifitas-aktifitas menulis. e) Peran efektif dari guru di dalam Belajar mandiri terjadi, seperti melakukan dialog dengan pelajar, melihat sumber pengetahuan yang aman, mengevaluasi hasil yang ada, dan berpikir secara kritis. f) Beberapa institusi pendidikan menemukan cara yang dapat mendukung kemandirian belajar seperti program pendidikan terbuka, pemilihan pendidikan bagi individu, dan program inovasi lainnya.

\section{Faktor-Faktor Yang Mempengaruhi Kemandirian Belajar}

Faktor-Faktor Yang Mempengaruhi Kemandirian Belajar menurut Muhammad Nur Syam (2009 :10), terbagi dua factor. Pertama, faktor internal yang ditandai dengan indikator tumbuhnya Kemandirian Belajar yang terpancar dalam fenomena antara lain: a. Sikap bertanggung jawab untuk melaksanakan apa yang dipercayakan dan ditugaskan b. Kesadaran hak dan kewajiban siswa disiplin moral yaitu budi pekerti yang menjadi tingkah laku c. Kedewasaan diri mulai konsep diri, motivasi sampai berkembangnya pikiran, karsa, cipta dan karya (secara berangsur) d. Kesadaran mengembangkan kesehatan dan kekuatan jasmani, rohani dengan makanan yang sehat, kebersihan dan olahraga e. Disiplin diri dengan mematuhi tata tertib yang berlaku, sadar hak dan kewajiban, keselamatan lalu lintas, menghormati orang 


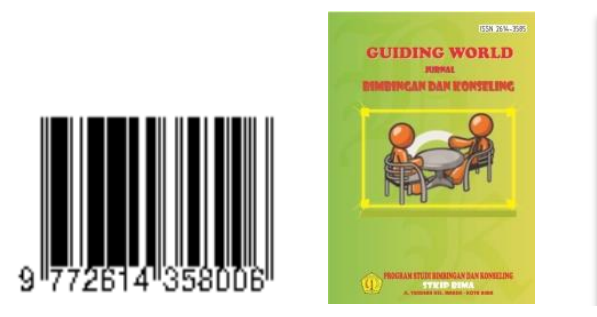

lain, dan melaksanakan kewajiban. Kedua faktor Eksogen atau faktor eksternal. Faktor ini berasal dari luar seperti keluarga, sekolah, dan masyarakat. Faktor ini sebagai pendorong kedewasaan dan Kemandirian Belajar meliputi: potensi jasmani rohani yaitu tubuh yang sehat dan kuat, lingkungan hidup, dan sumber daya alam, sosial ekonomi, keamanan dan ketertiban yang mandiri, kondisi dan suasana keharmonisan dalam dinamika positif atau negatif sebagai peluang dan tantangan meliputi tatanan budaya dan sebagainya secara komulatif

\section{Manfaat Kemandirian Belajar}

Banyak literarur yang mengungkap tentang kelebihan-kelebihan kemandirian belajar (Abdullah, 2011:90) dalam mengutip dari berbagai ahli memaparkan tentang keuntungankeuntungan kemandirian belajar. Orang yang melakukan kegiatan kemandirian belajar mendapatkan keuntungan-keuntungan sebagai berikut:

a. Mempunyai kesadaran dan tanggung jawab yang lebih besar dalam membuat pembelajaran menjadi bermakna terhadap dirinya sendiri.

b. Menjadi lebih penasaran untuk mencoba hal-hal baru.

c. Siswa pada kemandirian belajar memandang permasalahan sebagai tantangan yang harus dihadapi, minat belajar terus berkembang dan pembelajaran lebih menyenangkan.

d. Mereka menjadi termotivasi dan gigih, mandiri, disiplin-diri, percaya diri dan berorientasi pada tujuan.

e. Memungkinkan mereka belajar dan bersosialisasi dengan lebih efektif.

f. Mereka lebih mampu untuk mencari informasi dari berbagai sumber, menggunakan berbagai strategi untuk mencapai tujuan, dan dapat mengungkapkan gagasannya dengan format yang berbeda atau lebih kreatif.

\section{Pengertian Peer Group}

Peer group adalah kelompok teman anak sebaya yang sukses dimana dia dapat berinteraksi, Santoso (1999). Dalam kelompok teman sebaya (peer group), individu merasakan adanya kesamaan satu dengan yang lainnya seperti dibidang usia, kebutuhan dan tujuan yang dapat memperkuat kelompok itu. didalam peer group tidak dipentingkan adanya struktur organisasi, namun diantara anggota kelompok merasakan adanya tanggung jawab atas keberhasilan dan kegagalan kelompoknya. Dalam peer group ini, individu menemukan dirinya (pribadi) serta dapat mengembangkan rasa sosialnya sejalan dengan perkembangan kepribadiannya

Menurut pakar psikologi remaja Santrock, Cartwright dan Zander (www. compas. Com) "peer group adalah sekumpulan remaja sebaya yang punya hubungan erat dan saling tergantung. Maka disekolah atau dilingkungan tempat tinggal kita, biasanya ada kelompok pertemanan. Mereka terdiri atas beberapa orang yang merasa punya ikatan kuat. Mereka kelihatan selalu bersama-sama dalam melakukan berbagai aktivitas. Dalam kelompok teman sebaya (peer group) akan memungkinkan individu untuk saling berinteraksi, bergaul dan memberikan semangat dan motivasi terhadap teman sebaya yang lain secara emosional. Adanya ikatan secara emosional dalam kehidupan peer group akan mendatangkan berbagai manfaat dan pengaruh yang besar bagi individu yang berada dalam kelompok tersebut.

Menurut Shahabuan, dkk (2003) menjelaskan bahwa kelompok sebaya ( peer group ) adalah agen penting yang mempengaruhi pembentukan dan perkembangan individu. Menurut 


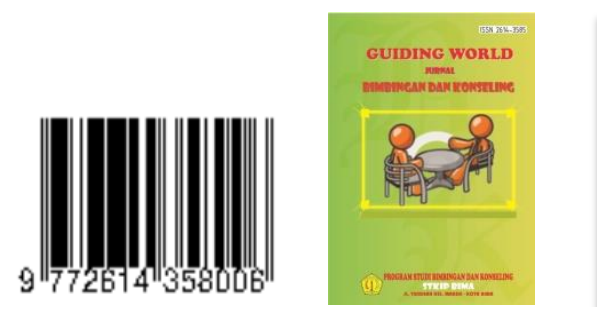

Malecki \& Elliott, (1999) kelompok sebaya merupakan sekumpulan remaja yang sama dari segi umur, pendidikan, atau kelas sosial dan minat.

Berdasarkan beberapa pendapat diatas, dapat disimpulkan bahwa peer group adalah sekelompok teman sebaya yang mempunyai ikatan emosional yang kuat dan mereka dapat berinteraksi, bergaul, bertukar pikiran, dan pengalaman dalam memberikan perubahan dan pengembangan dalam kehidupan sosial dan pribadinya.

\section{Fungsi Peer Group}

Sebagaimana kelompok sosial yang lain maka peer group juga mempunyai fungsi. Menurut Santoso (1999) fungsi-fungsi peer group tersebut adalah sebagai berikut :

a. Mengajarakan kebudayaan. Dalam peer group diajarkan kebudayaan yang berada ditempat itu.

b. Mengajarkan mobilitas sosial. Mobilitas sosial adalah perubahan status yang lain. Misalnya dalam kelas menengah dan kelas rendah (tingkat sosial) dengan adanya kelas rendah pindah ke kelas menengah itulah yang dinamakan mobilitas.

c. Membantu peranan sosial yang baru. Peer group memberikan kesempatan bagi anggotanya untuk mengisi peranan sosial yang baru. Misalnya anak yang belajar bagaimana menjadi pemimpin kelompok yang baik.

d. Peer Group sebagai sumber informasi bagi orang tua dan guru bahkan untuk masyarakat. Kelompok teman sebaya disekolah bisa sebagai sumber informasi bagi guru dan orang tua tentang hubungan sosial individu dan seseorang yang berprestasi baik dapat dibandingkan dalam kelompoknya.

e. Dalam peer group individu dapat mencapai ketergantungan satu sama lain. Karena dalam peer group ini mereka dapat merasakan kebersamaan dalam kelompok, mereka saling ketergantungan satu sam lainnya.

f. Peer Group mengajarkan moral orang dewasa. Anggota peer group bersikap dan bertingkah laku. seperti orang dewasa untuk mempersiapkan diri menjadi orang dewasa mereka memperoleh kemantapan sosial.

g. Di dalam peer group individu dapat mencapai kebebasan sendiri. Kebebasan disini diartikan sebagai kebebasan untuk berpendapat, bertindak dan menemukan identitas diri. Karena dalam kelompok itu, anggota-anggota yang lainnya juga mempunyai tujuan dan keinginan yang sama.

h. Di dalam peer group, anak -anak mempunyai organisasi sosial yang baru. Dengan adanya kelompok sosial seperti peer group tersebut akan memberikan ruang dan waktu kepada individu untuk berubah dan berkembang sesuai dengan tingkat usia dan perkembangan pribadinya dalam aspek kehidupan sosialnya. Mereka akan mengalami perubahan dalam berbagai hal yang memungkinkan untuk berperan menjadi lebih luas dalam kehidupan kelompok sosialnya yang ditandai dengan perubahan sikap dan perilakunya.

Dalam peer group, mereka akan bersikap lebih dewasa dan berusaha untuk dapat setara dan memberikan sesuatu yang bermanfaat dalam kelompoknya, seperti belajar untuk menjadi pemimpin kelompok yang baik, memberikan kontribusi dan pengaruh terhadap kelompok dengan suasana yang menyenangkan dan penuh dengan keleluasaan dan kebebasan dalam menemukan identitas diri dan juga konsep dirinya. 


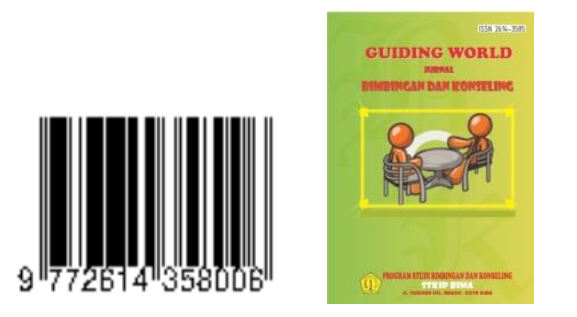

\section{Ciri - Ciri Peer Group}

Adapun ciri-ciri peer group adalah sebagai berikut :

a. Tidak mempunyai struktur organisasi yang jelas, Maksudnya kelompok teman sebaya terbentuk secara spontan., diantara anggota kelompok mempunyai kedudukan yang sama. tetapi ada satu diantara anggota kelompok yang dianggap sebagai pemimpin yang dianggap oleh semua orang anggota, bahwa dia memang pantas dijadikan sebagai pemimpin. Pemimpin biasanya adalah orarng yang disegani dalam kelompok itu.

b. Bersifat sementara, karena tidak ada struktur organisasi yang jelas, kelompok ini tidak bisa bertahan lama.

c. Peer group mengajarkan individu tentang kebudayaan yang luas. Misalnya teman sebaya disekolah, mereka umumnya terdiri dari individu yang berbeda lingkungannya yang mempunyai aturan dan kebiasaan yang berbeda-beda. Lalu mereka memasukkannya dalam kelompok yang sebaya sehingga mereka saling belajar secara tidak langsung tentang kebiasaan itu dan dipilih yang sesuai dengan kelompoknya, kemudian dijadikan kebiasaan kelompoknya.

d. Anggotanya adalah individu yang sebaya. Contoh kongkretnya pada anak-anak yang usia SMP atau SMA.

\section{Pengaruh Perkembangan Peer Group}

a. Pengaruh positif dari peer group adalah :

1. Apabila invidu didalam kehidupannya memiliki peer group maka mereka akan lebih siap menghadapi kehidupan yang akan datang.

2. Individu dapat mengembangkan rasa solidaritas antar kawan.

3. Bila individu masuk dalam peer group maka setiap anggota akan dapat membentuk masyarakat yang akan direncanakan sesuai dengan kebudayaan yang mereka anggap baik.

4. Setiap anggota dapat berlatih memperoleh pengetahuan kecakapan dalam melatih bakatnya

5. Mendorong individu untuk bersifat mandiri

6. Menyalurkan perasaan dan pendapat demi kemajuan kelompok.

b. Pengaruh Negatif dari Peer Group adalah :

1. Sulit menerima seseorang yang tidak mempunyai kesamaan

2. Tertutup bagi individu lain yang tidak termasuk anggota

3. Menimbulkan rasa iri pada anggota satu dengan yang lain yang tidak memiliki kesamaan dengan dirinya

4. Timbul persaingan antar anggota kelompok

5. Timbul pertentangan/gap-gap antar kelompok sebaya

\section{Pengertian Motivasi Belajar}

Motivasi dan belajar merupakan dua hal yang saling mempengaruhi. Pengertian motivasi dan belajar secara terpisah memiliki arti yang berbeda-beda menurut pendapat para ahli psikologi diantaranya : 


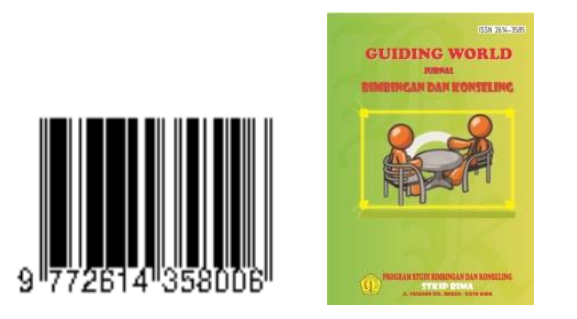

a. Pengertian Motivasi menurut Sumadi Suryabrata dalam buku psikologi pendidikan (1994) adalah keadaan yang terdapat dalam diri seseorang yang mendorongnya untuk melakukan aktivitas tertentu guna pencapaian suatu tujuan.

b. Pengertian motivasi menurut Arthur J. Gates (Educational Psychology) seperti yang dikutip oleh Djaali dalam buku psikologi pendidikan (2008) mengungkapkan bahwa motivasi adalah suatu kondisi fisiologi dan psikologi yang terdapat dalam diri seseorang yang mengatur tindakannya dengan cara tertentu untuk mencapai suatu tujuan

c. Berkaitan dengan pengertian motivasi yang lain, menurut Hamzah B. Uno dalam buku Teori Motivasi dan pengukurannya (2008) menjelaskan arti motivasi sebagai Konstruk Hipotesis yang digunakan individu untuk menjelaskan keinginan, arah, intensitas dan keajegan perilaku yang diarahkan oleh tujuan

Berdasarkan pendapat diatas yang dimaksud motivasi dalam pengertian ini adalah suatu kondisi fisiologis dan psikologi yang terdapat dalam diri seseorang yang mengatur tindakannya dengan cara tertentu untuk mencapai suatu tujuan.

Dari pendapat tentang belajar diatas, maka yang dimaksud dengan belajar dalam penelitian ini dapat disimpulkan sebagai suatu proses perubahan tingkah laku secara relatif permanen dan secara potensial terjadi sebagai hasil dari penguatan yang dilandasi tujuan untuk mencapai tujuan tertentu. Sedangkan hakikat motivasi belajar itu sendiri menurut Hamzah B. Uno dalam buku Teori Motivasi \& Pengukuran (2008) Menyimpulkan definisi motivasi belajar sebagai :

Dorongan internal dan eksternal yang meliputi kondisi fisiologi dan psikologi pada siswa yang sedang belajar untuk mengadakan perubahan tingkah laku secara relatif permanen dan potensial sebagai hasil dari penguatan untuk mencapai tujuan tertentu.

\section{Unsur - Unsur Motivasi Belajar}

Betapa pentingnya motivasi dalam belajar, karena keberadaanya sangat berarti bagi perbuatan belajar. Karena tujuan motivasi dalam belajar sebagai pengarah untuk perbuatan belajar. Kepada tujuan yang jelas yang diharapkan dapat tercapai. Adapun unsurunsur/indikator penting dalam motivasi belajar menurut Hamzah B. Uno dalam buku Teori Motivasi dan pengukurannya (2008) mengklasifikasikan sebagai berikut :

a. Adanya hasrat dan keinginan berhasil

b. Adanya dorongan dan kebutuhan dalam belajar

c. Adanya harapan dan cita-cita masa depan.

d. Adanya penghargaan dalam belajar

e. Adanya kegiatan menarik dalam belajar

f. Adanya lingkungan belajar yang kondusif

Berdasarkan unsur-unsur motivasi dalam belajar diatas dapat disimpulkan bahwa dalam motivasi belajar mencakup sejumlah konsep seperti dorongan (drive) ,kebutuhan (need), rangsangan (incentive), ganjaran (reward), penguatan (reinforcement), ketetapan tujuan (goal setting), dan harapan (expectancy).

\section{Faktor - Faktor yang Mempengaruhi Motivasi Belajar}

Menurut Ngalim Purwanto dalam buku psikologi pendidikan (2004) faktor - faktor yang mempengaruhi belajar diantaranya : 


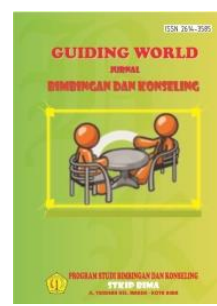

1. Faktor individual meliputi : kematangan/pertumbuhan, kecerdasan, latihan, motivasi, sifat kepribadian (fisik kesehatan dan kondisi badan).

2. Faktor sosial meliputi : keadaan keluarga, guru dan cara mengajar, media pembelajaran, motivasi social (kelompok sebayanya), lingkungan dan kesempatan masyarakat sekitar.

Menurut Djaali dalam buku psikologi pendidikan (2008) faktor-faktor yang mempengaruhi belajar yaitu :

1. Faktor internal (faktor dari dalam diri) meliputi : kesehatan, intelegensi, motivasi, minat, kebiasaan belajar, konsep diri.

2. Faktor Eksternal (faktor dari luar diri) meliputi :

2.1 Keluarga termasuk didalamnya : situasi keluarga, pendidikan orarng tua, status ekonomi, rumah kediaman, persentase hubungan orang tua.

2.2 Sekolah, termasuk didalamnya : gedung sekolah, kualitas guru, perangkat instrumen pendidikan, lingkungan sekolah dan rasio guru dan murid perkelas.

2.3 Masyarakat, termasuk didalamnya : tempat tinggal, masyarakat sekitar, tingkat pendidikan masyarakat sekitar.

2.4 Lingkungan sekitar, termasuk didalamnya : keadaan lalu lintas, iklim, pengaruh media massa.

\section{Upaya Meningkatkan Motivasi Belajar}

Upaya untuk meningkatkan motivasi belajar menurut. Dimayati dalam buku belajar dan pembelajaran (2006) menyebutkan upaya untuk meningkatkan motivasi belajar diantaranya :

1. Optimalisasi penerapan prinsip belajar

Perilaku belajar disekolah telah menjadi pola umum. Sejak usia enam tahun. Siswa masuk sekolah selama lima- enam jam sehari. Upaya pembelajaran terkait dengan beberapa prinsip belajar tersebut. Antara lain sebagai berikut : (1) belajar menjadi bermakna bila siswa memahami tujuan belajar, oleh karena itu guru perlu menjelaskan tujuan belajar secara hierarkis. Tujuan belajar memahami dan menhafal syair lagu Indonesia Raya, misalnya agar siswa dapat menyanyikan lagu tersebut dengan baik. (2) Belajar menjadi bermakna bila siswa dihadapkan pada pemecahan masalah yang menantangnya; oleh karena itu peletakan urutan masalah yang menantang harus disusun guru dengan baik. (3) Belajar menjadi bermakna bila guru mampu memusatkan segala kemampuan mental siswa dalam program kegiatan tertentu; oleh karena itu, disamping mengajarkan bahan secara terpisah-pisah, guru sebaiknya, membuat pembelajaran dalam pen gajaran unit atau proyek.

2. Optimalisasi dinamis sarana belajar dan pembelajaran

Guru adalah pendidik dan sekaligus pembimbing belajar. Guru lebih memahami keterbatasan waktu bagi siswa. Seringkali siswa lengah tentang nilai kesempatan belajar. Oleh karena itu guru dapat mengupayakan optimalisasi unsur-unsur dinamis yang ada dalam diri sebagai berikut : (1) Pemberian kesempatan pada siswa untuk mengungkap hambatan belajar yang dialaminya. (2) Memelihara minat, kemauan dan semangat belajarnya sehingga terwujud tindak belajar, betapa lambat gerak belajar, Guru " tetap secara terus menerus". Mendorong; dalam hal ini berlaku semboyan " lambat asal selamat takkan lari gunung dikejar". (3) Meminta kesempatan pada orang tua siswa atau wali, agar memberi kesempatan pada siswa untuk beraktualisasi diri dalam belajar. (4) 

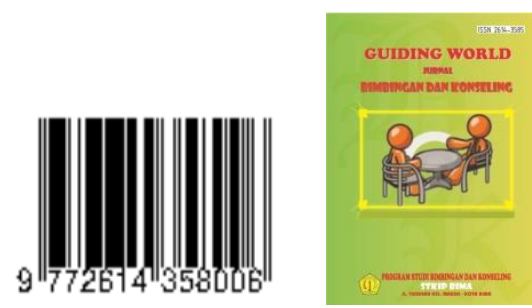

DOI: 1033627

Volume 04, Nomor 01

Mei 2021

E-ISSN: 2614-3585

Memanfaatkan unsur-unsur lingkungan yang mendorong belajar, Misalnya : surat kabar dan tayangan TV yang mengganggu pemusatan perhatian belajar agar dicegah. (5) Menggunakan waktu secara tertib, penguat dan suasana gembira terpusat pada perilaku belajar, pada tingkat ini guru memberlakukan upaya "belajar merupakan aktualisasi diri siswa". (6) Guru merangsang siswa dengan penguatan memberi rasa percaya diri bahwa dia dapat mengatasi segala hambatan dan "pasti berhasil";

3. Optimalisasi pemanfaatan pengalaman dan kemampuan siswa

Perilaku belajar siswa merupakan rangkaian tindak-tindak belajar setiap hari. Perilaku belajar setiap hari bertolak dari jadwal pelajaran sekolah. Untuk menghadapi hari pertama masuk sekolah guru telah membuat rancangan pengajaran. Sedangkan siswa telah terbiasa dengan membaca buku pelajaran. Siswa telah mengalami belajar yang berhasil atau belajar yang gagal sebelumnya. Siswa menghayati "pahitnya kegagalan". Belajar, dan " manisnya keberhasilan belajar". Oleh karena itu rancangan pengajaran satu tahun ajaran selalu diharapkan oleh seluruh siswa. Bagi siswa, rancangan tersebut ibarat "perjalanan tamasyah kegunung yang penuh liku-liku, yang sulit tetapi menggembirakan". Kehadiran hari pertama yang "penuh harap". Pada siswa perlu digunakan untuk membesarkan semangat belajar.

4. Optimalisasi pengembangan cita-cita masa depan dan aspirasi belajar.

Dalam rangka pengembangan cita-cita belajar, guru dan pendidik lain dapat membuat program-program belajar. Program-program belajar yang dapat dilakukan bersama antara lain sebagai berikut: (i) Program lomba baca yang diselenggarakan untuk menyambut hari kemerdekaan; dalam hal ini sekolah, masyarakat desa, lembaga agama, pramuka, membuat kegiatan bersama (ii) Program lomba karya tulis ilmiah, seni rupa, kerajinan, untuk kreativitas seni, dan (iii) Program belajar kebaktian sosial bagi siswa. Dengan demikian dapat dikemukakan bahwa pengembangan cita-cita belajar tersebut "di tempuh" dengan jalan membuat kegiatan belajar sesuatu. Penguat berupa hadiah diberikan pada setiap siswa yang berhasil. Sebaliknya, dorongan keberanian untuk memiliki cita-cita diberikan kepada setiap siswa yang berasal dari semua lapisan masyarakat.

Dari uraian diatas dapat ditarik suatu kesimpulan bahwa untuk meningkatkan motivasi belajar dapat dilakukan berbagai upaya meliputi peningkatan prinsip belajar, sarana belajar dan pembelajaran, pengalaman dan kemampuan siswa serta cita-cita dan aspirasi belajar kearah masa depan. Dengan demikian motivasi belajar akan meningkat secara maksimal serta hasil dan tujuan belajarpun akan mendapatkan hasil yang maksimal pula.

\section{Pengaruh Peer Group Terhadap Motivasi Belajar}

Motivasi pada dasarnya merupakan upaya untuk membantu dalam memahami dan menjelaskan perilaku individu yang sedang belajar. Motivasi dan belajar merupakan dua hal yang saling mempengaruhi. Keberadaan motivasi sangatlah berarti bagi perbuatan belajar. Selain itu motivasi merupakan pengarah untuk perbuatan belajar kepada tujuan yang jelas yang diharapkan dapat tercapai. Jadi motivasi belajar adalah dorongan internal dan eksternal yang meliputi kondisi fisiologis dan psikologis pada siswa yang sedang belajar untuk mengadakan perubahan tingkah laku secara relatif permanen dan potensial sebagai hasil dari penguatan untuk mencapai tujuan tertentu.

Dalam motivasi belajar mengandung aspek dorongan, kebutuhan, rangsangan, ganjaran, penguatan, ketetapan tujuan dan harapan. Motivasi belajar yang timbul dari tiap 


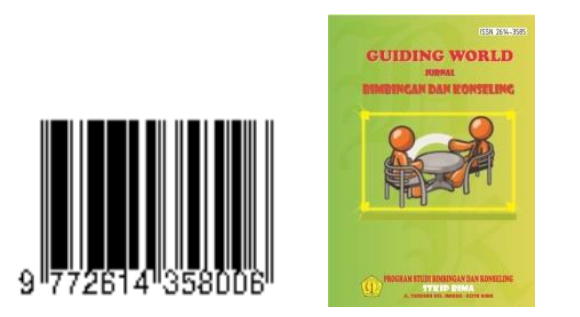

siswa sangat dipengaruhi oleh berbagai faktor yang terkait dengan faktor belaja. Faktor yang mempengaruhi faktor motivasi belajar dibedakan atas faktor internal dan eksternal. Faktor internal adalah dorongan dari dalam diri meliputi intelegensi, minat, bakat, cita-cita, kebiasaan belajar dan konsep diri. Sedangkan faktor eksternal adalah dorongan dari luar dirinya meliputi : faktor lingkungan salah satunya adalah kelompok teman sebaya (peer group)

Peer Group adalah sekumpulan remaja sebaya yang punya hubungan erat dengan saling tergantung. Maka disekolah maupun dilingkungan tempat tinggal, biasanya ada kelompok pertemanan. Mereka terdiri atas beberapa orang yang merasa punya ikatan kuat. Dalam kelompok teman sebaya (peer group) akan memungkinkan individu untuk saling berinteraksi, bergaul dan memberikan semangat dan motiivasi terhadap teman sebaya yang lain secara emosional. Dan pada akhirnya dengan adanya ikatan secara emosional dalam kehidupan peer group akan mendatangkan berbagai manfaat dan pengaruh yang besar bagi individu yang berada dalam kelompok tersebut salah satunya adalah peningkatan motivasi belajar.

\section{METODE}

Jenis penelitian ini termasuk penelitian kuantitatif karena menggunakan rancangan Empiris. Subyek dalam penelitian ini adalah siswa kelas VIII yang tergabung dalam 8 peer Group dengan jumlah 31 orang di SMP Negeri 8 Kota Bima Sedangkan untuk pengambilan sampel melalui simple random sampling (cara acak). Instrumen penelitian menggunakan angket dan dokumentasi. Tehnik analisa data yang digunakan adalah korelasi produk moment.

\section{HASIL DAN PEMBAHASAN}

\section{Deskripsi Data}

Data yang dideskripsikan pada bab ini adalah data hasil olahan dari rekapitulasi data lengkap yang terdapat pada lampiran skripsi ini. Data yang dimaksud adalah data menurut variabel yang diteliti yang disajikan dalam tabel penyajiannaya. Data tersebut adalah data hasil pengolahan angket yang disajikan dalam bentuk angka-angka serta di angka-angka serta di cross check dengan nilai rapor siswa yang menjadi subjek penelitian.

Tabel Data Angket Peer Group (X) dan Motivasi Belajar Siswa (Y) SMP Negeri 8 Kota Bima

\begin{tabular}{|c|c|c|c|}
\hline No & Subyek & $\mathrm{X}$ & $\mathrm{Y}$ \\
\hline 1 & $\mathrm{AA}$ & 60 & 55 \\
\hline 2 & $\mathrm{AB}$ & 60 & 55 \\
\hline 3 & $\mathrm{AC}$ & 59 & 54 \\
\hline
\end{tabular}




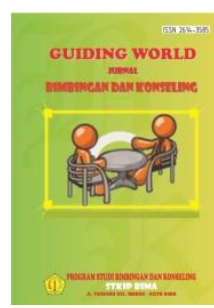

DOI: 1033627

\begin{tabular}{|c|c|c|c|}
\hline 4 & $\mathrm{AD}$ & 58 & 58 \\
\hline 5 & $\mathrm{AE}$ & 63 & 57 \\
\hline 6 & $\mathrm{AF}$ & 61 & 62 \\
\hline 7 & $\mathrm{AG}$ & 60 & 62 \\
\hline 8 & $\mathrm{AH}$ & 62 & 62 \\
\hline 9 & AI & 50 & 56 \\
\hline 10 & AJ & 52 & 53 \\
\hline 11 & $\mathrm{AK}$ & 56 & 56 \\
\hline 12 & $\mathrm{AL}$ & 50 & 58 \\
\hline 13 & $\mathrm{AM}$ & 58 & 58 \\
\hline 14 & AN & 58 & 61 \\
\hline 15 & $\mathrm{AO}$ & 55 & 63 \\
\hline 16 & AP & 58 & 65 \\
\hline 17 & $\mathrm{AQ}$ & 70 & 66 \\
\hline 18 & AR & 66 & 69 \\
\hline 19 & $\mathrm{AS}$ & 65 & 69 \\
\hline 20 & $\mathrm{AT}$ & 67 & 69 \\
\hline 21 & $\mathrm{AU}$ & 67 & 71 \\
\hline 22 & $\mathrm{AV}$ & 52 & 65 \\
\hline 23 & AW & 55 & 66 \\
\hline 24 & $\mathrm{AX}$ & 55 & 63 \\
\hline 25 & AY & 60 & 70 \\
\hline 26 & $\mathrm{AZ}$ & 58 & 53 \\
\hline 27 & $\mathrm{BA}$ & 61 & 59 \\
\hline 28 & $\mathrm{BB}$ & 59 & 61 \\
\hline 29 & $\mathrm{BC}$ & 54 & 67 \\
\hline 30 & $\mathrm{BD}$ & 56 & 63 \\
\hline 31 & $\mathrm{BE}$ & 55 & 62 \\
\hline
\end{tabular}

\section{Analisis Data Dan Pengujian Hipotesis}

1. Analisis Data

a. Korelasi Product Moment

Berdasarkan data yang diperoleh selanjutnya dilakukan analisis data dan pengujian hipotesis penelitian. Oleh karena itu disiapkan tabel untuk memudahkan perhitungan korelasi product moment.

Tabel Perhitungan Korelasi Product Moment 

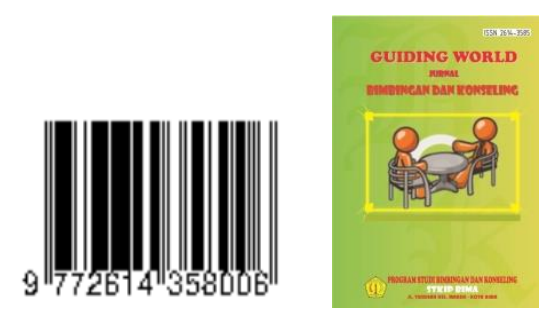

GUIDING WORLD JURNAL

BIMBINGAN DAN KONSELING

Volume 04, Nomor 01

Mei 2021

E-ISSN: 2614-3585

DOI: 1033627

\begin{tabular}{|c|c|c|c|c|c|}
\hline No & $X$ & $\mathrm{Y}$ & $X^{2}$ & $\mathrm{Y}^{2}$ & XY \\
\hline 1 & 60 & 55 & 3600 & 3025 & 3300 \\
\hline 2 & 60 & 55 & 3600 & 3025 & 3300 \\
\hline 3 & 59 & 54 & 3481 & 2916 & 3186 \\
\hline 4 & 58 & 58 & 3364 & 3364 & 3364 \\
\hline 5 & 63 & 57 & 3969 & 3249 & 3591 \\
\hline 6 & 61 & 62 & 3721 & 3844 & 3782 \\
\hline 7 & 60 & 62 & 3600 & 3844 & 3720 \\
\hline 8 & 62 & 62 & 3844 & 3844 & 3844 \\
\hline 9 & 50 & 56 & 2500 & 3136 & 2800 \\
\hline 10 & 52 & 53 & 2704 & 2809 & 2756 \\
\hline 11 & 56 & 56 & 3136 & 3136 & 3136 \\
\hline 12 & 50 & 58 & 2500 & 3364 & 2900 \\
\hline 13 & 58 & 58 & 3364 & 3364 & 3364 \\
\hline 14 & 58 & 61 & 3364 & 3721 & 3538 \\
\hline 15 & 55 & 63 & 3025 & 3969 & 3465 \\
\hline 16 & 58 & 65 & 3364 & 4225 & 3770 \\
\hline 17 & 70 & 66 & 4900 & 4356 & 4620 \\
\hline 18 & 66 & 69 & 4356 & 4761 & 4554 \\
\hline 19 & 65 & 69 & 4225 & 4761 & 4485 \\
\hline 20 & 67 & 69 & 4489 & 4761 & 4623 \\
\hline 21 & 67 & 71 & 4489 & 5041 & 4757 \\
\hline 22 & 52 & 65 & 2704 & 4225 & 3380 \\
\hline 23 & 55 & 66 & 3025 & 4356 & 3630 \\
\hline 24 & 55 & 63 & 3025 & 3969 & 3465 \\
\hline 25 & 60 & 70 & 3600 & 4900 & 4200 \\
\hline 26 & 58 & 53 & 3364 & 2809 & 3074 \\
\hline 27 & 61 & 59 & 3721 & 3481 & 3599 \\
\hline 28 & 59 & 61 & 3481 & 3721 & 3599 \\
\hline 29 & 54 & 67 & 2916 & 4489 & 3618 \\
\hline 30 & 56 & 63 & 3136 & 3969 & 3528 \\
\hline 31 & 55 & 62 & 3025 & 3844 & 3410 \\
\hline Jumlah & 1820 & 1908 & 107592 & 118278 & 112358 \\
\hline
\end{tabular}

Selanjutnya subtitusi nilai pada tabel di atas pada persamaan korelasi product moment yaitu sebagai berikut:

$$
r_{X Y}=\frac{N \sum X Y-\left(\sum X\right)\left(\sum Y\right)}{\sqrt{\left\{N \sum X^{2}-\left(\sum X\right)^{2}\right)\left(N \sum Y^{2}-\left(\sum Y\right)^{2}\right\}}}
$$




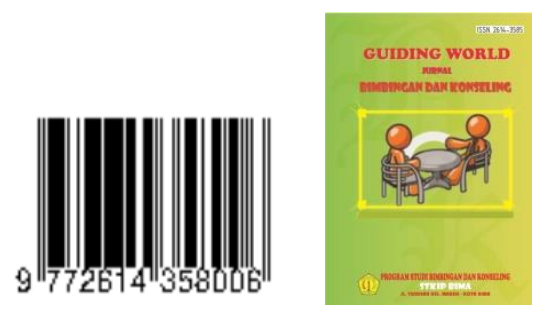

$$
\begin{aligned}
& =0.43 \\
& =43 \%
\end{aligned}
$$

b. Analisis deskriptif peer group dan motivasi belajar siswa.

\begin{tabular}{|c|l|c|c|}
\hline \multirow{2}{*}{ No } & \multicolumn{1}{|c|}{ Aspek yang diteliti } & $\%$ & $\begin{array}{c}\text { Kategori } \\
\text { hambatan }\end{array}$ \\
\hline \multirow{4}{*}{1} & Peranan Peer Group & 85,27 & Baik sekali \\
\cline { 2 - 4 } & a. Ikatan emosional & 30,22 & Kurang \\
\cline { 2 - 4 } & b. Interaksi dengan sesama & 28,17 & Kurang \\
\cline { 2 - 4 } & c. Kemampuan bergaul & 24,30 & Kurang \\
\cline { 2 - 4 } & d. Kemampuan bertukar pikiran dengan orang lain & 27,74 & Kurang \\
\cline { 2 - 4 } & e. Mempunyai pengalaman bergaul & \multicolumn{1}{|c|}{} \\
\hline \multirow{4}{*}{2.} & Motivasi Belajar & 52,47 & Sedang \\
\cline { 2 - 4 } & a. Internal & 23,87 & Kurang \\
\cline { 2 - 4 } & 1. Keinginan diri dalam bergaul & 43,87 & Sedang \\
\cline { 2 - 4 } & 2. Perubahan tingkah laku & 23,87 & Kurang \\
\cline { 2 - 4 } & 3. Mengenal Potensi & 61,08 & Baik \\
\cline { 2 - 4 } & 4. Tujuan yang ingin dicapai & \multicolumn{2}{|c|}{} \\
\cline { 2 - 4 } & b. Eksternal & \multicolumn{2}{|c|}{} \\
\hline
\end{tabular}

\section{Pengujian Hipotesis}

Sebelum pengujian hipotesis, terlebih dahulu merumuskan hipotesis awal (Ho) dan hipotesis alternatif (Ha).

Hipotesis awal (Ho) dalam penelitian ini adalah tidak ada pengaruh peer group terhadap motivasi belajar siswa SMP Negeri 8 Kota Bima Tahun Pelajaran 2009/2010. Hipotesis awal diterima apabila nilai korelasi product moment (r) adalah nol (0). Jika sebaliknya maka Ho tertolak. Tertolaknya Ho berarti Ha diterima.

Berdasarkan perhitungan korelasi product moment diperoleh nilai yaitu 0.43 (43\%), sehingga dapat disimpulkan bahwa ada pengaruh positif peer group terhadap motivasi belajar siswa di SMP Negeri 8 Kota Bima.

\section{PENUTUP}

Berdasarkan hasil analisa data yang dilakukan oleh peneliti sebelumnya maka ada beberapa aspek yang mempengaruhi peranan guru matematika dalam pelaksanaan bimbingan kelompok adalah sebagai berikut :

1. Aspek peningkatan motivasi belajar siswa

2. Aspek peningkatan keterampilan belajar siswa

3. Aspek proses belajar

4. Aspek pengembangan sikap dan kebiasaan belajar yang baik

Untuk memperoleh hasil penelitian yang baik terhadap adanya keempat aspek tersebut peneliti menetapkan persentase dari masing-masing aspek. adapun besar persentase yang diperoleh dalam 4 (empat) aspek tersebut adalah Aspek peningkatan motivasi belajar siswa 


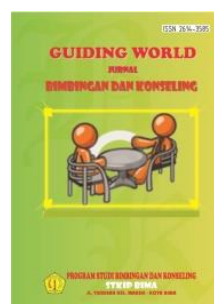

DOI: 1033627

Volume 04, Nomor 01

Mei 2021

E-ISSN: 2614-3585

menghasilkan $72,81 \%$ tergolong baik, Aspek peningkatan keterampilan belajar siswa menghasilkan 61\% tergolong baik, Aspek proses belajar menghasilkan 68,71\% tergolong baik, sedangkan Aspek pengembangan sikap dan kebiasaan belajar yang baik menghasilkan $80,67 \%$ tergolong sangat baik, sehingga peranan guru matematika dalam pelaksanaan bimbingan kelompok siswa kelas VIII SMPN 1 Kota Bima pada umumnya tergolong baik.

\section{DAFTAR PUSTAKA}

[1] Abdullah. 2011. Belajar dan Faktor-Faktor Yang Mempengaruhinya. Jakarta: Rineka Cipta.

[2] Ahmadi, A. 2000. Psikologi Pendidikan dan Evaluasi Belajar. Jakarta: Gramedia

[3] Algifari. 2000. Analisis Regresi Teori,Kasus, dan Solusi. Yogyakarta: BPFE.

[4] Ali, Muhammad. 2001. Guru dalam Proses Belajar Mengajar. Bandung: Sinar Baru.

[5] Amir, A. 2010. Pedoman Penulisan Karya Ilmiah. STKIP Bima: CV. Usaha Tunggal.

[6] Antonius, 2002. Hubungan antara Kemandirian dengan prestasi belajar karya kerajinan tangan pada siswa kelas I SD Negeri Bulu Lor 01-03 Semarang tahun pelajaran 2004/2005. "Skripsi" tidak diterbitkan

[7] Arikunto, S. 2002. Prosedur Penelitian Suatu Pendekatan Praktek. Jakarta: Rineka Cipta.

[8] Barnadib, Imam. 2002. Filsafat Pendidikan. Yogyakarta: Adi Citra.

[9] Depdiknas. 2003. Undang-Undang RI No. 20 Tahun 2003 Tentang Sistem Pendidikan Nasional (SISDIKNAS). Jakarta: Depdiknas.

[10] Susilawati, D. 2009. Kemandirian Belajar dan Faktor-Faktor Yang Mempengaruhinya. Jakarta: Rineka Cipta.

[11] Wibowo, E. 1992. Evaluasi Pengajaran (Prinsip dan Teknik). Bandung: Remaja Rosdakarya

[12] Gunarso, D Singgih. 2000. Psikologi Praktis, anak, Remaja, dan Keluarga. Jakarta : BPK Gunung Mulia.

[13] Haris Mujiman, 2005. Meningkatkan Kemandirian Belajar Simposium Peranan Psikilogi dalam Usaha Meningkatkan Prestasi Belajar. Surabaya, Sie Psikologi, bag. Psikiatri Fakultas Kedokteran UNAIR.

[14] Hasbullah. 2008. Peran Keluarga dalam Mencerdaskan anak. Jakarta : BPK Gunung Mulia.

[15] Iswardono. 1981. Analisa Regresi dan Korelasi. Yogyakarta: BPFE UGM.

[16] Masrun, 2001. Pengaruh Kemandirian belajar tehadap hasil belajar pada mata pelajaran Ekonomi pada siswa kelas XI IPS SMA Negeri 2 Semarang tahun pejaran 2005/2006. "Skripsi” tidak diterbitkan.

[17] Moleong, L,J. 2000. Metode Penelitian Kualitatif. Bandung: PT. Remaja Rosdakarya.

[18] Riduwan, 2004. Belajar Mudah Penelitian Untuk Guru-Karyawan dan Peneliti Pemula. Alfabeta Bandung

[19] Sadojah. 2002, Pengantar Bimbingan dan Penyuluhan Belajar di Sekolah. Surabaya; Usaha Nasional

[20] Saodah, Sukmadinata, N. 2007. Bimbingan dan Konseling. Bandung: Maestro.

[21] Sadirman, AM, 1986. Interaksi dan Motivasi Belajar Mengajar. Jakarta : Rajawali.

[22] Slavin, 2004. Prestasi belajar dan Kompetensi Guru. Jakarta : Gramedia 